Journal of Current Medical Research and Opinion

\title{
Prevalence of Tuberculosis in Al-Falluja, Iraq 2012-2018
}

\author{
Mahmood H. Mahmood ${ }^{\star, \dagger}$
}

M.B.CH.B, DPLOMA

DOI: https://doi.org/10.15520/jcmro.v2i11.227

Accepted 01-11-2019; Received 05-10-2019; Publish Online 10-11-2019

\author{
Reviewed By: \\ Dr. V Daniel \\ Department: \\ Reviewer/CMRO
}

\begin{abstract}
Background: Tuberculosis is an infectious bacterial disease caused by mycobacterium tuberculosis and produce tubercle in tissue, affect mainly the lung (pulmonary TB) but can affect any other part of body (extra-pulmonary TB).

Objective: This study aimed at studying the prevalence of tuberculosis in Al-Falluja city, Iraq for the period of 2012-2018.

Method: By retrospective study, the following data were studied from patient record at Al-Wihdda health center in Al-Fallujah, Iraq (age, gender, and type of tuberculosis) Result: The total number of the patients in 2012 were 86 cases. Females were affected more than male, The ratio (female $47=55 \%$ and male $39=45 \%$ ). The patients of age group (15-24) year old had experienced detected Tuberculosis cases of N (SS+). Females of age group of (65 and more) year old had experienced detected Tuberculosis cases of EPTB. All cases of Relapse were had detected in males. EPTB and N $(\mathrm{SS}+)$ more than others in this year. The total number of patients in 2013 were 102 cases. Females were affected more than male, the ratio (female $52=51 \%$ and male $50=49 \%)$. Female patients in age group of (15-24) and (25-34) year old had experienced detected Tuberculosis cases of N (SS+), Males in age group of (0-1) year old had experienced detected Tuberculosis cases of EPTB, females in age group of (55-64) year old had experienced detected Tuberculosis cases of EPTB while in age group of (15-24) year old males had experienced detected Tuberculosis cases of EPTB more than females. Males in age group of (65 and more) year old had experienced detected Tuberculosis cases of Relapse more than females. Females in age group of (55-64) year old had experienced detected Tuberculosis cases of N (SS-). EPTB and N (SS+) more than other types in this year. The total number of the patients in 2017 were 51 cases. Females were affected more than males, the ratio (female $27=53 \%$ and male $24=47 \%$ ). Male patients had experienced detected Tuberculosis cases of EPTB, Relapse, and N (SS-) more than females. Females had experienced detected tuberculosis cases of $\mathrm{N}$ (SS+). EPTB and N (SS+) more than other types in this year.

The Total number of the patients in 2018 were 60 cases. Females were affected more than males, the ratio (female $36=60 \%$ and male $24=40 \%$ ). Female patients in age group of (5-14) year old had experienced detected Tuberculosis cases of EPTB, male in age group of (55-64) year old had experienced detected Tuberculosis cases of N (SS+). Females had experienced detected Tuberculosis cases of Relapse, N (SS-) and (ND, $\mathrm{NA}$ ) more than males. EPTB and $\mathrm{N}(\mathrm{SS}+)$ more than other types in this year.
\end{abstract}

Conclusion: Female patients are affected more than male by Tuberculosis.

Recommendation:

Our study can recommend:

1. Spreading health awareness about tuberculosis as a health problem for all people by organize an awareness program in which people learn about what is Tuberculosis and how to benefit from its treatment.

2. Tuberculosis care through the Iraqi Ministry of Health.

Abbreviations:

TB: tuberculosis. PTB: pulmonary tuberculosis

EPTB: Extra-pulmonary tuberculosis. N (SS+): New Sputum Smear Positive. N (SS-): New Sputum Smear Negative. HIV: Human Immunodeficiency Virus. WHO: World Health Organization.

Key words: Prevalence-Tuberculosis-Falluja City-Iraq 


\section{INTRODUCTION:}

Tuberculosis is one of the top 10 causes of death and the leading cause from a single infectious agent (above HIV/AIDS). Millions of people continue to fall sick with TB each year. In 2017, TB caused an estimated 1.3 million deaths (range, 1.2-1.4) among HIV-negative people and there were an additional 300000 deaths from TB (range, 266 000-335 000) among HIV-positive people [1]. Iraq is considered to be a middle burden country with TB, and occupies rank 108 globally and 7 in eastern Mediterranean region among countries with TB burden size. According to WHO report, the estimated incidence of TB in Iraq is $45 / 100000$ population (I.e estimated total new TB cases is around 15000 per year), while the prevalence is $74 / 100000$ and the mortality is $3 / 100000$ [2].

In 2017, the largest number of new TB cases occurred in the South- East Asia and Western Pacific region, with $62 \%$ of new cases, followed by African region, with $25 \%$ of new cases [3].

Tuberculosis is spread from person to person through the air. When people with lung TB cough, sneeze, or spit, they propel the TB germs into the air. A person needs to inhale only a few of these germs to become infected. About onequarter of the worlds population has latent TB, Which mean people have been infected by TB bacteria but are not (yet) ill with the disease and cannot transmit the disease [4].

The present study aimed to find out the prevalence of Tuberculosis in Al-Falluja city, Iraq

\section{METHODOLOGY:}

A retrospective study design was applied throughout the present study from the period of August 12th 2019 to October 8th 2019 in order to identify the tuberculosis cases in Al-Falluja city, Iraq for 2012-2018 except three years (20142015-2016) due to the security conditions experienced by Iraq since second half of 2014 and the provinces of Anbar, Nineveh, Salah al-Din, Kirkuk and Diyala have been subjected to the terrorist attacks and Al-Falluja was among them. A convenient sample of (299) registered patients with tuberculosis in Al-Falluja, Iraq for the period 2012-2018 except the years of conflict. The following data were studied from patient record at Al-Wihdda health center in AlFalluja, Iraq (age, gender, and type of tuberculosis).

\section{RESULTS:}

Table 1 : Show females were affected more than male, The ratio (female $47=55 \%$ and male $39=45 \%$ ). The patients of age group (15-24) year old had experienced detected Tuberculosis cases of $\mathrm{N}(\mathrm{SS}+)$. Females of age group of (65 and more) year old had experienced detected Tuberculosis cases

\footnotetext{
* Corresponding author.

$\dagger$ Email: wmowm55@gmail.com
}

of EPTB. All cases of Relapse were had detected in males. EPTB and N (SS+) more than others in this year.

Table $2:$.Show females were affected more than male, the ratio (female $52=51 \%$ and male $50=49 \%$ ). Female patients in age group of (15-24) and (25-34) year old had experienced detected Tuberculosis cases of N (SS+), Males in age group of (0-1)year old had experienced detected Tuberculosis cases of EPTB more than female, females in age group of (55-64)year old had experienced detected Tuberculosis cases of EPTB while in age group of (15-24) year old males had experienced detected Tuberculosis cases of EPTB more than females. Males in age group of (65 and more) year old had experienced detected Tuberculosis cases of Relapse more than females. Females in age group of (55-64) year old had experienced detected Tuberculosis cases of N (SS-). EPTB and $\mathrm{N}(\mathrm{SS}+)$ more than other types in this year.

Table 3 : Show females were affected more than males, the ratio (female $27=53 \%$ and male $24=47 \%$ ). Male patients had experienced detected Tuberculosis cases of EPTB, Relapse, and N (SS-) more than females. Females had experienced detected tuberculosis cases of $\mathrm{N}(\mathrm{SS}+)$. EPTB and $\mathrm{N}$ $(\mathrm{SS}+)$ more than other types in this year.

Table 4 : Show female patients in age group of (5-14) year old had experienced detected Tuberculosis cases of EPTB, male in age group of (55-64) year old had experienced detected Tuberculosis cases of N (SS+). Females had experienced detected Tuberculosis cases of Relapse, N (SS-) and (ND, NA) more than males. EPTB and $\mathrm{N}(\mathrm{SS}+)$ more than other types in this year.

\section{DISCUSSION:}

This study describes the prevalence of Tuberculosis in four years period in Al-Falluja City, Iraq. In our study we depend on documented data in patients' records in Al-Wihdda health center. Due to the security conditions experienced by Iraq since second half of 2014 and the provinces of Anbar, Nineveh, Salah al-Din, Kirkuk and Diyala have been subjected to the terrorist attacks that led to displacement of many Tuberculosis patients registered in these hot spots and led to loss of communication with these patients so we could not catch up the Tuberculosis cases in this city in 2014-2015-2016.

\section{CONCLUSION:}

\section{Conclusion:}

Based on the study findings, the study can conclude:

1. Females in age group of (15-24) year old had experienced detected Tuberculosis cases more than males of all age group.

2. There were detected Tuberculosis cases in age group of (0-1) year old and these cases were in 2012 and 2013 while absence like these cases in 2017 and 2018 and in these two years the males had experienced detected Tuberculosis cases of New Extra-pul than females. 
Table 1. Detected TB cases According to the Age, Genderin Al-Falluja, Iraq Year (2012)

\begin{tabular}{|c|c|c|c|c|c|c|c|c|c|c|c|c|c|c|c|c|c|c|c|c|c|}
\hline \multirow[t]{2}{*}{ Type of TB } & \multicolumn{2}{|c|}{$0-1$} & \multicolumn{2}{|c|}{$1-4$} & \multicolumn{2}{|c|}{$5-14$} & \multicolumn{2}{|c|}{$15-24$} & \multicolumn{2}{|c|}{$25-34$} & \multicolumn{2}{|c|}{$35-44$} & \multicolumn{2}{|c|}{$45-54$} & \multicolumn{2}{|c|}{$55-64$} & \multicolumn{2}{|c|}{$\begin{array}{l}\text { 65or } \\
\text { more }\end{array}$} & \multicolumn{2}{|c|}{ total } & \multirow[b]{2}{*}{$\mathrm{T}$} \\
\hline & $\mathrm{M}$ & $\mathrm{F}$ & $\mathrm{M}$ & $\mathrm{F}$ & $\mathrm{M}$ & $\mathrm{F}$ & $\mathrm{M}$ & $\mathrm{F}$ & $\mathrm{M}$ & $\mathrm{F}$ & $\mathrm{M}$ & $\mathrm{F}$ & $\mathrm{M}$ & $\mathrm{F}$ & $\mathrm{M}$ & $\mathrm{F}$ & $\mathrm{M}$ & $\mathrm{F}$ & $\mathrm{M}$ & $\mathrm{F}$ & \\
\hline $\mathrm{N} \mathrm{SS}+)$ & 0 & 0 & 0 & 0 & 0 & 1 & 4 & 7 & 2 & 2 & 0 & 3 & 1 & 2 & 1 & 3 & 2 & 1 & 10 & 19 & 29 \\
\hline Relapse & 0 & 0 & 0 & 0 & 0 & 0 & 0 & 0 & 1 & 0 & 1 & 0 & 1 & 0 & 1 & 0 & 1 & 0 & 5 & 0 & 5 \\
\hline After failre & 0 & 0 & 0 & 0 & 0 & 0 & 0 & 1 & 0 & 0 & 0 & 0 & 0 & 0 & 0 & 0 & 0 & 0 & 0 & 1 & 1 \\
\hline After default & 0 & 0 & 0 & 0 & 0 & 0 & 0 & 0 & 0 & 0 & 0 & 0 & 0 & 0 & 0 & 0 & 0 & 0 & 0 & 0 & 0 \\
\hline N (SS-) & 0 & 0 & 0 & 0 & 0 & 0 & 0 & 1 & 0 & 1 & 0 & 1 & 0 & 0 & 1 & 0 & 1 & 0 & 2 & 3 & 5 \\
\hline$(\mathrm{ND}, \mathrm{NA})$ & 0 & 0 & 0 & 0 & 1 & 1 & 0 & 0 & 0 & 0 & 0 & 0 & 0 & 0 & 0 & 0 & 0 & 0 & 1 & 1 & 2 \\
\hline $\mathrm{N}(\mathrm{EP})$ & 1 & 0 & 0 & 0 & 4 & 4 & 3 & 3 & 4 & 2 & 2 & 2 & 3 & 4 & 1 & 2 & 2 & 5 & 20 & 22 & 42 \\
\hline other & 1 & 1 & 0 & 0 & 0 & 0 & 0 & 0 & 0 & 0 & 0 & 0 & 0 & 0 & 0 & 0 & 0 & 0 & 1 & 1 & 2 \\
\hline total & 3 & & 0 & & 11 & & 19 & & 12 & & 9 & & 11 & & 9 & & 12 & & 39 & 47 & 86 \\
\hline
\end{tabular}

Table 2. Detected TB cases According to the Age, Genderin Al-Falluja, Iraq Year (2013)

\begin{tabular}{|c|c|c|c|c|c|c|c|c|c|c|c|c|c|c|c|c|c|c|c|c|c|}
\hline \multirow[t]{2}{*}{ Type of TB } & \multicolumn{2}{|c|}{$0-1$} & \multicolumn{2}{|c|}{$1-4$} & \multicolumn{2}{|c|}{$5-14$} & \multicolumn{2}{|c|}{$15-24$} & \multicolumn{2}{|c|}{$25-34$} & \multicolumn{2}{|c|}{$35-44$} & \multicolumn{2}{|c|}{$45-54$} & \multicolumn{2}{|c|}{$55-64$} & \multicolumn{2}{|c|}{$\begin{array}{l}65 \text { or } \\
\text { more }\end{array}$} & \multicolumn{2}{|c|}{ Total } & \multirow[b]{2}{*}{$\mathrm{T}$} \\
\hline & $\mathrm{M}$ & $\mathrm{F}$ & $\mathrm{M}$ & $\mathrm{F}$ & $\mathrm{M}$ & $\mathrm{F}$ & $\mathrm{M}$ & $\mathrm{F}$ & $\mathrm{M}$ & $\mathrm{F}$ & $\mathrm{M}$ & $\mathrm{F}$ & $\mathrm{M}$ & $\mathrm{F}$ & $\mathrm{M}$ & $\mathrm{F}$ & $\mathrm{M}$ & $\mathrm{F}$ & $\mathrm{M}$ & $\mathrm{F}$ & \\
\hline $\mathrm{N}(\mathrm{SS}+)$ & 0 & 0 & 0 & 0 & 0 & 1 & 4 & 6 & 6 & 6 & 2 & 1 & 1 & 1 & 3 & 2 & 0 & 1 & 16 & 18 & 34 \\
\hline Relapse & 0 & 0 & 0 & 0 & 1 & 0 & 0 & 0 & 0 & 1 & 1 & 0 & 0 & 0 & 1 & 0 & 2 & 0 & 5 & 1 & 6 \\
\hline After failure & 0 & 0 & 0 & 0 & 0 & 0 & 0 & 0 & 0 & 0 & 0 & 0 & 0 & 0 & 0 & 0 & 0 & 0 & 0 & 0 & 0 \\
\hline After default & 0 & 0 & 0 & 0 & 0 & 0 & 0 & 1 & 0 & 0 & 0 & 0 & 0 & 0 & 1 & 0 & 0 & 0 & 1 & 1 & 2 \\
\hline N (SS-) & 0 & 0 & 0 & 0 & 0 & 1 & 0 & 0 & 1 & 1 & 1 & 0 & 0 & 0 & 1 & 2 & 0 & 0 & 3 & 4 & 7 \\
\hline$(\mathrm{ND}, \mathrm{NA})$ & 0 & 0 & 0 & 0 & 0 & 0 & 0 & 0 & 0 & 0 & 0 & 0 & 0 & 0 & 0 & 0 & 0 & 0 & 0 & 0 & 0 \\
\hline $\mathrm{N}(\mathrm{EP})$ & 3 & 2 & 0 & 0 & 5 & 2 & 8 & 6 & 2 & 3 & 5 & 3 & 2 & 3 & 0 & 8 & 0 & 1 & 25 & 28 & 53 \\
\hline Other & 0 & 0 & 0 & 0 & 0 & 0 & 0 & 0 & 0 & 0 & 0 & 0 & 0 & 0 & 0 & 0 & 0 & 0 & 0 & 0 & 0 \\
\hline Total & 5 & & 0 & & 10 & & 25 & & 20 & & 13 & & 7 & & 18 & & 4 & & 50 & 52 & 102 \\
\hline
\end{tabular}

Table 3. Detected TB cases According to the Age, Genderin Al-Falluja, Iraq Year (2017)

\begin{tabular}{|c|c|c|c|c|c|c|c|c|c|c|c|c|c|c|c|c|c|c|c|c|c|}
\hline \multirow[t]{2}{*}{ Type of TB } & \multicolumn{2}{|c|}{$0-1$} & \multicolumn{2}{|c|}{$1-4$} & \multicolumn{2}{|c|}{$5-14$} & \multicolumn{2}{|c|}{$15-24$} & \multicolumn{2}{|c|}{$25-34$} & \multicolumn{2}{|c|}{$35-44$} & \multicolumn{2}{|c|}{$45-54$} & \multicolumn{2}{|c|}{$55-64$} & \multicolumn{3}{|c|}{65 or more } & \multicolumn{2}{|c|}{ Total } \\
\hline & $\mathrm{M}$ & $\mathrm{F}$ & $\mathrm{M}$ & $\mathrm{F}$ & M & $\mathrm{F}$ & $\mathrm{M}$ & $\mathrm{F}$ & $\mathrm{M}$ & $\mathrm{F}$ & $\mathrm{M}$ & $\mathrm{F}$ & $\mathrm{M}$ & $\mathrm{F}$ & $\mathrm{M}$ & $\mathrm{F}$ & $\mathrm{M}$ & $\mathrm{F}$ & $\mathrm{M}$ & $\mathrm{F}$ & $\mathrm{T}$ \\
\hline $\mathrm{N}(\mathrm{SS}+)$ & 0 & 0 & 0 & 0 & 0 & 2 & 0 & 2 & 1 & 1 & 0 & 1 & 0 & 1 & 0 & 2 & 0 & 0 & 1 & 9 & 10 \\
\hline Relapse & 0 & 0 & 0 & 0 & 0 & 1 & 0 & 0 & 1 & 0 & 1 & 0 & 0 & 0 & 0 & 0 & 0 & 0 & 2 & 1 & 3 \\
\hline After failure & 0 & 0 & 0 & 0 & 0 & 0 & 0 & 0 & 0 & 0 & 0 & 0 & 0 & 0 & 0 & 0 & 0 & 0 & 0 & 0 & 0 \\
\hline After default & 0 & 0 & 0 & 0 & 0 & 0 & 0 & 0 & 0 & 0 & 0 & 0 & 0 & 1 & 0 & 0 & 0 & 0 & 0 & 1 & 1 \\
\hline N (SS-) & 0 & 0 & 0 & 0 & 0 & 0 & 0 & & 0 & 1 & 1 & 0 & 1 & 0 & 0 & 0 & 0 & 0 & 2 & 1 & 3 \\
\hline$(\mathrm{ND}, \mathrm{NA})$ & 0 & 0 & 0 & 0 & 0 & 0 & 0 & 0 & 1 & 0 & 0 & 0 & 0 & 1 & 0 & 0 & 0 & 0 & 1 & 1 & 2 \\
\hline $\mathrm{N}(\mathrm{EP})$ & 1 & 0 & 1 & 0 & 1 & 0 & 4 & 2 & 3 & 4 & 2 & 2 & 2 & 3 & 2 & 2 & 2 & 1 & 18 & 14 & 32 \\
\hline Other & 0 & 0 & 0 & 0 & 0 & 0 & 0 & 0 & 0 & 0 & 0 & 0 & 0 & 0 & 0 & 0 & 0 & 0 & 0 & 0 & 0 \\
\hline Total & 1 & & 1 & & 4 & & 8 & & 12 & & 7 & & 9 & & 6 & & 3 & & 24 & 27 & 51 \\
\hline
\end{tabular}

Table 4. Detected TB cases According to the Age, Genderin Al-Falluja, Iraq Year (2018)

\begin{tabular}{|c|c|c|c|c|c|c|c|c|c|c|c|c|c|c|c|c|c|c|c|c|c|}
\hline \multirow[t]{2}{*}{ Type of TB } & \multicolumn{2}{|c|}{$0-1$} & \multicolumn{2}{|c|}{$1-4$} & \multicolumn{2}{|c|}{$5-14$} & \multicolumn{2}{|c|}{$15-24$} & \multicolumn{2}{|c|}{$25-34$} & \multicolumn{2}{|c|}{$35-44$} & \multicolumn{2}{|c|}{$45-54$} & \multicolumn{2}{|c|}{$55-64$} & \multicolumn{2}{|c|}{$\begin{array}{l}\text { 65or } \\
\text { more }\end{array}$} & \multicolumn{2}{|c|}{ Total } & \multirow[b]{2}{*}{$\mathrm{T}$} \\
\hline & $\mathrm{M}$ & $\mathrm{F}$ & M & $\mathrm{F}$ & M & $\mathrm{F}$ & $\mathrm{M}$ & $\mathrm{F}$ & M & $\mathrm{F}$ & M & $\mathrm{F}$ & $\mathrm{M}$ & $\mathrm{F}$ & $\mathrm{M}$ & $\mathrm{F}$ & M & $\mathrm{F}$ & $\mathrm{M}$ & $\mathrm{F}$ & \\
\hline $\mathrm{N}(\mathrm{SS}+)$ & 0 & 0 & 0 & 0 & 0 & 0 & 1 & 5 & 2 & 2 & 2 & 1 & 2 & 0 & 3 & 0 & 0 & 0 & 10 & 8 & 18 \\
\hline Relapse & 0 & 0 & 0 & 0 & 0 & 0 & 0 & 1 & 0 & 0 & 0 & 0 & 1 & 0 & 0 & 1 & 0 & 1 & 1 & 3 & 4 \\
\hline After failure & 0 & 0 & 0 & 0 & 0 & 0 & 0 & 0 & 0 & 0 & 0 & 0 & 0 & 0 & 0 & 0 & 0 & 0 & 0 & 0 & 0 \\
\hline After default & 0 & 0 & 0 & 0 & 0 & 0 & 0 & 0 & 0 & 0 & 0 & 1 & 0 & 0 & 0 & 0 & 0 & 0 & 0 & 1 & 1 \\
\hline N (SS-) & 0 & 0 & 0 & 2 & 0 & 0 & 1 & 0 & 0 & 1 & 0 & 1 & 0 & 0 & 0 & 0 & 0 & 0 & 1 & 4 & 5 \\
\hline$(\mathrm{ND}, \mathrm{NA})$ & 0 & 0 & 0 & 0 & 0 & 0 & 0 & 2 & 0 & 1 & 0 & 0 & 0 & 0 & 0 & 0 & 0 & 0 & 0 & 0 & 0 \\
\hline $\mathrm{N}(\mathrm{EP})$ & 0 & 0 & 1 & 0 & 2 & 5 & 1 & 2 & 4 & 1 & 2 & 2 & 0 & 1 & 1 & 3 & 1 & 3 & 12 & 17 & 29 \\
\hline Other & 0 & 0 & 0 & 0 & 0 & 0 & 0 & 0 & 0 & 0 & 0 & 0 & 0 & 0 & 0 & 0 & 0 & 0 & 0 & 0 & 0 \\
\hline total & 0 & & 3 & & 7 & & 13 & & 11 & & 9 & & 4 & & 8 & & 5 & & 24 & 36 & 60 \\
\hline
\end{tabular}


3. Relapes cases were found in Males more frequently than females in 2012 and 2013, while females were more in $2018 \ldots$

4. New extra-pul TB (EPTB) is the type in female patient, while new pulmonary $\mathrm{TB}(\mathrm{PTB})(\mathrm{SS}+)$ is the type in male patient in 2018 .

5. New PTB (SS-) were more detected in females in all these years.

\section{Recommendation:}

Our study can recommend:

1.Spreading health awareness about tuberculosis as a health problem for all people by organize an awareness program in which people learn about what is Tuberculosis and how to benefit from its treatment

2.Tuberculosis care through the Iraqi Ministry of Health.

\section{REFERENCES}

[1] Global Health Observatory (GHO) data $>$ Tuberculosis.

[2] WHO (2019) epidemiology (PDF), Global tuberculosis control epidemiology, strategy, financy p.p6-33..

[3] Tuberculosis-World Health Organization, 2018

[4] https://www.who.int/news-room/fact-sheets/detail/tuberculosis. 